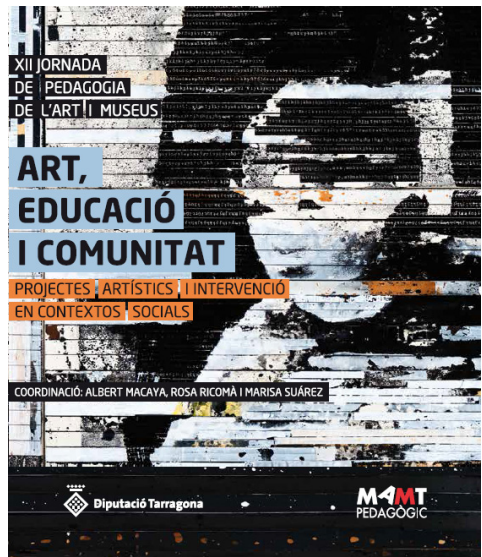

XII Jornada de Pedagogia de l'Art i Museus. Art, Educació $i$ Comunitat. Projectes artístics $i$ intervenció en contextos socials

Albert Macaya, Rosa Ricomà i Marisa Suarez (coord.)

Any: 2015. Lloc: Tarragona

Diputació de Tarragona.

Pàgines: 156

ISBN: 978-84-15264-43-9

\title{
L'educació artística al museu: una eina per a la transformació social
}

Des de l'any 2000 el Museu d'Art Modern de Tarragona acull anualment les jornades de Pedagogia de 1'Art i Museus en col·laboració amb la Universitat Rovira i Virgili. L'objectiu d'aquestes jornades és el de reflexionar al voltant de les relacions i llaços existents entre els centres educatius i els museus, especialment d'art, així com fer visible la importancia dels museus com àmbits d'intercanvi i d'aprenentatge. Aquest llibre recull les propostes dels diferents professionals que es van reunir el 29 d'abril de 2015 al MAMT en la XII Jornada de Pedagogia de 1'Art i Museus nomenada Art, educación i comunitat.

Com alumna del Diploma en Educació Artística i Gestió de Museus de la Universitat de València, vaig tindre el plaer d'escoltar en una de les sessions a Marisa Suárez, una de les dues responsables del Servei Pedagògic del Museu. Amb gran humilitat, Marisa ens va explicar que les educadores d'aquest Servei Pedagògic es consideren "facilitadores" que, d'una manera horitzontal, proporcionen als ciutadans les eines necessàries per a la comprensió de l'art contemporàni. A més, les educadores impliquen a l'observador i el fan partícip donant-li veu, al comunicar l'obra d'art com un relat obert que pot tindre tants significats com visitants recorren el Museu. Al MAMT donen molta importància a les persones, amb les quals mantenen un viu diàleg, les cuiden i les escolten amb atenció perquè creuen sincerament en la funció educativa a través de 1'art per a transformar la societat.

Aquest volum comença amb la presentació del treball desenvolupat a l'àrea de Mediació del Centro Internacional de Cultura Contemporánea -Tabakalera- de Donostia des de finals de 2013. Tabakalera naix amb una doble vocació, la de ser un centre de producció i la d'oferir una programació pública d'activitats. Amb aquest plantejament de fomentar la creació, l'exhibició i la formació a partir de la reflexió i la investigació, els mediadors del Centre Nerea Hernández, Ana Revuelta, Javier Rodrigo i Leire San Martín expliquen com a partir d'aquest emblemàtic edifici, les propostes artístiques i culturals programades i les seues accions com educadors han aconseguit dinamitzar el barri d'Egia. Per poder plantejar els diferents projectes, 
van començar a encercar els ritmes, les sinergies i les necessitats del barri amb una metodologia "d'escolta activa" i d'implicació amb els diferents agents, col·lectius i associacions. Fruit d'aquests contactes, s'enceten 3 línies de treball: pedagogies i espai públic, educació i narratives audiovisuals i pedagogies feministes. A més, els mediadors expliquen interessants experiències amb centres escolars i espais culturals del barri, entenent les àrees de mediació de les institucions com a generadores i activadores de pensament.

En segon lloc, Pablo Coca, coordinador d'Educació del Museo Patio Herreriano de Valladolid, parla de la importancia dels museus d'art contemporàni com espais oberts, inclusius i d'atenció a la diversitat, propers als interessos i inquietuds dels ciutadans. El Patio Herreriano tracta de fer accesibles tant el propi espai museogràfic com les seues col·leccions i exposicions. Al departament de Recerca i Educació del Museu han estat col·laborant amb diferents institucions a través de programes que es centren en persones amb diversitat funcional, tant psíquica com intel·lectual. Al projecte "ARTErias con locura", en marxa des de 2013, la pràctica creativa es presenta com una eina inclusiva d'alliberament que canalitza els sentiments, les inquietuds i els desitjos de les persones que pateixen algun tipus de trastorn mental. Així, aquest procés terapèutic serveix com un dispositiu d'autoconeixement, d'autoexploració i d'autoconstrucció personal.

En tercer 1loc, Francisco Rubio i Àgia Luna, coordinadors de diferents entitats, ens expliquen el funcionament d'Artibarri, una xarxa d'entitats, d'associacions i de professionals catalans que promou tasques artístiques al servei de la transformació social, com a eina de canvi a través d'un procés de pedagogia crítica. En contra de la idea de la creació artística com a producte de la genialitat individual, a Artibarri se li dóna importancia a les persones de diferents grups i col·lectius cercant valors de democracia cultural i de treball en xarxa per tot el territori català. Aquest projecte iniciat 1'any 2002, té com a objectiu generar un espai de reflexió, d'intercanvi de recursos, de formació i de recerca sobre la creativitat com a mitjà d'intervenció comunitària. Alguns dels projectes artístics que es duen a terme a Artibarri són l'obra de teatre contra el racisme Mustafà és al replà, el festival Artescape que barreja diferents disciplines com ara música, grafit, capoeira i circ o xerrades col·lectives a instituts de secundària.

En quart 1loc, el director artístic d'ACVic (Centre d'Arts Contemporànies de Vic), Ramon Parramon, planteja una reflexió sobre les practiques artístiques i els processos educatius en el marc de l'espai social. Els espais d'aprenentatge no són sols l'escola, l'institut o la universitat; en són molts i molt diversos, ja que al llarg de la vida es produeixen successius processos pedagògics dins i fora dels àmbits formals. A més, la universitat es veu com un espai híbrid en el que es poden aglutinar diferents disciplines catalitzades per la creativitat artística i que té com a conseqüència 1'activació social. Per una altra banda, des de 1'ACVic mostren exemples de projectes que han impulsat des de la pràctica artística per incidir en el 
context social (hi participen escoles, universitats, centres d'art, etc.): "Art i escola" i "Hibridacions i contextos".

Finalment, Cristian Añó, coordinador dels projectes de mediació "microRavals" i "Pedagogies de Fricció", reflexiona al voltant dels conceptes d'educació, mediació, el seu camp d'acció i el context on es desenvolupen aquestes iniciatives. El projecte "microRavals" impulsa processos culturals i artístics que impliquen a diferents institucions, col-lectivitats, entitats i comunitats arrelades al barri del Raval de Barcelona. Algunes exposicions plantejades al Centre d'Arts Santa Mónica són el punt de partida per a encetar un treball col-laboratiu entre els artistes de les mostres, els mediadors i diferents escoles, col-lectius, comunitats i centres de dia per a persones grans. D'aquesta relació sorgeix un gran marc de cooperació que es tradueix en una xarxa cultural d'intercanvi força enriquidora per als agents que la conformen.

Lucía Marrades. Universitat de València 